\title{
Reserve Status
}

National Cancer Institute

\section{Source}

National Cancer Institute. Reserve Status. NCI Thesaurus. Code C114857.

The status of an individual who is serving in a reserve branch of any of the United States Uniformed Services. 